\title{
Dryland Horticulture in Maupiti: An Ethnoarchaeological Study
}

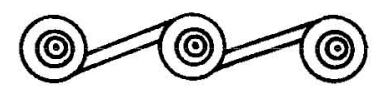

\author{
MICKAELLE-HINANUI CAUCHOIS
}

THE RESUlTS OF A FIELD STUDY OF DRYLAND HORTICULTURE ${ }^{1}$ on the island of Maupiti (Society Islands, French Polynesia) are presented here. This work is an extension of an exhaustive archaeological survey of this island made in 1980 and completed in 1998 by Eric Conte (Université de Polynésie Française). The main purpose was to study how dryland horticulture is practiced today and to compare the results with ethnohistoric sources to achieve a better understanding, if possible, of pre-European horticulture. The fact that no visible horticultural remains were found in Maupiti was a leitmotiv to investigate how dryland cultivation might have been practiced in the past, in what kind of environment, and with what kind of technological features. One of the main questions was to investigate how horticulture may have been carried out on steep mountain slopes, which characterize Maupiti. Furthermore, an important criterion for the choice of Maupiti was the possibility of working on a small island that has been largely "protected" from mechanized agriculture.

The study was divided into several parts. The mission was preceded by a compilation of the ethnohistoric sources concerning the different aspects of dryland horticulture on the islands of French Polynesia and Polynesia to construct a general theoretical framework. Concerning the whole of Polynesia, particular attention was attached to ethnographic studies of a similar kind (e.g., Barrau 1965a, 1965b; Best 1925; Buck 1938; Di Piazza 1993; Handy 1923, 1940; Kirch 1976, 1994). It was followed by the preparation of a set of questions addressed to the Maupiti farmers concerning different aspects of dryland horticultural practices. The most important part of the work was carried out in the field in Maupiti from mid-December to mid-January 1998. We were accompanied by Maui Tauvirai of Maupiti, who was a great help to us. Thanks to him and his valuable advice, we were able to meet the farmers and were assisted in the translation from Tahitian to French. Informant responses were complemented by schematic maps and photographs of the fields. These materials were analyzed within the scope of a Master's thesis (Cauchois 1999). Some technical information was corrected by an agronomist. ${ }^{2}$ This paper summarizes the results of this work in a broader perspec-

Mickaelle-Hinanui Cauchois is affiliated with the Service du Patrimoine, Ministère de la Culture, French Polynesia.

Asian Perspectives, Vol. 41, No. 2 (C) 2002 by University of Hawai'i Press. 
tive and explores the possibilities of using an ethnoarchaeological approach for investigating dry and wetland horticulture in French Polynesia.

\section{METHODS}

After scrutinizing the ethnohistoric sources, some constraints and limitations became apparent. For example, there was no detailed description of the Maupiti landscape or its gardens in these sources. For the Society Islands in general, Dana Lepofsky (Lepofsky 1994) had proposed an interesting summary of six different types of horticultural systems occurring in high island environments, drawing upon the three main kinds of ethnohistoric sources (late eighteenth-century voyagers, missionaries, later memoirs). On the whole, the analyzed information corroborated the idea that dryland horticulture has been a neglected aspect of Polynesian horticulture. As Kirch explained it (Kirch 1994:10), this negligence has for a long time hidden a fundamental feature that sweeps aside a generally accepted idea: systems where fallowing predominates are those that require greater labor (see also Boserup 1970). Failing to perceive the real complexity of horticultural systems, early European testimonies (e.g., Cook 1998; Ferdon 1981) offer us a set of uneven descriptions that form today the main basis for understanding preEuropean subsistence systems.

The set of questions that I wished to pose to the Maupiti farmers was developed after this initial ethnohistorical review. The questions were prepared around three main issues: (1) cultivated species and varieties, (2) cultural practices (techniques), and (3) the purpose of cultivation. These questions were refined while investigating different aspects of the fields and their configuration. The investigations were followed up with schematic maps and photographs of the fields illustrating different aspects of horticultural work. Six fields were selected according to the availability of the farmers, three on the coastal plain, and three in the mountains. One of our purposes was to examine dryland cultivation on different degrees of slope.

\section{ENVIRONMENTAL SETTING}

Located $350 \mathrm{~km}$ northwest of Tahiti, Maupiti is a small high island whose total area does not exceed $12 \mathrm{~km}^{2}$ (Fig. 1). Surrounded by a lagoon, several islets, and a coral reef, the main island (whose ancient name is Maurua ${ }^{3}$ ) is $327 \mathrm{~m}$ high. The coastal plain is quite narrow. Especially dry, Maupiti has neither rivers nor streams, and does not support any kind of traditional wet horticulture, such as taro irrigation. Orographically, there is no real difference in precipitation between the narrow coastal plain and the mountains.

The six fields chosen for study are concentrated in the southwestern part of the island, in Ta'atoi (Fig. 2). The fields are quite modest; they vary between 600 and $11,000 \mathrm{~m}^{2}$. The mountain fields are larger in area, characterized by slopes varying between 25 and 40 percent. Those located on the coastal plain are partly flat with a slope of around 20 percent, used especially for taro.

Concerning the environmental features, fields in the mountains hold more moisture because they are surrounded by dense vegetation. In contrast, fields on the coastal plain are directly exposed to the sun. Even if there is not much differ- 


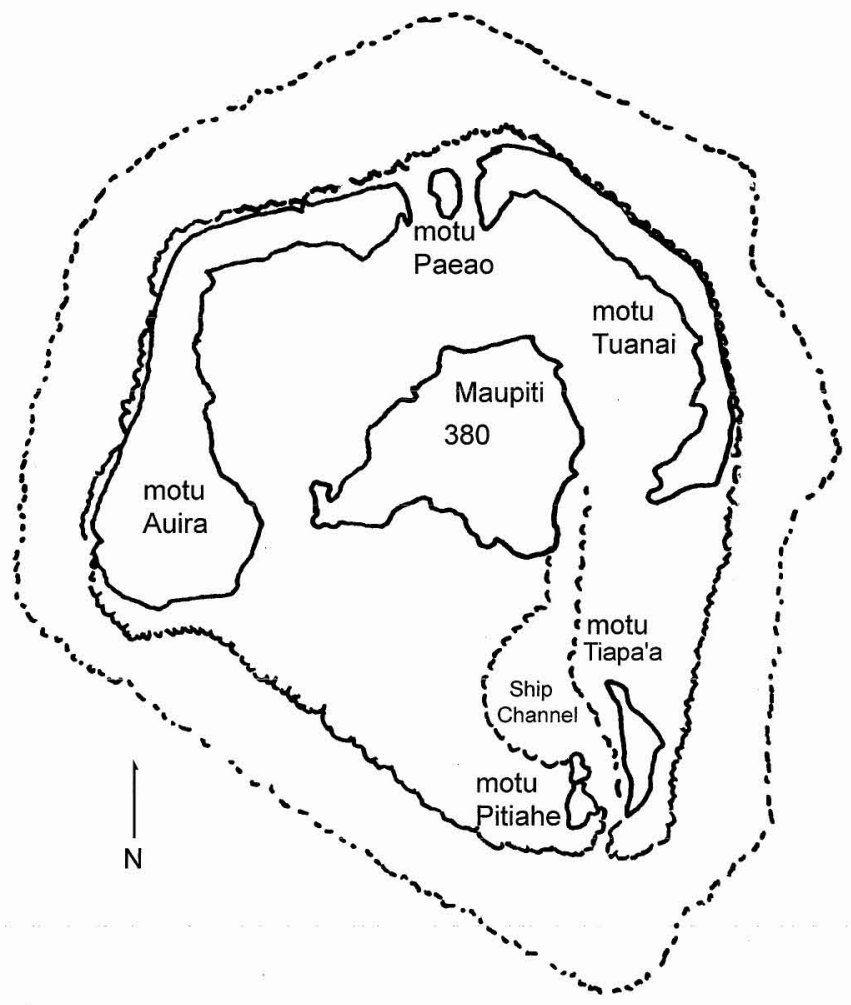

Fig. 1. Maupiti Island (after IGN map no. 513, $1: 100,000)$.

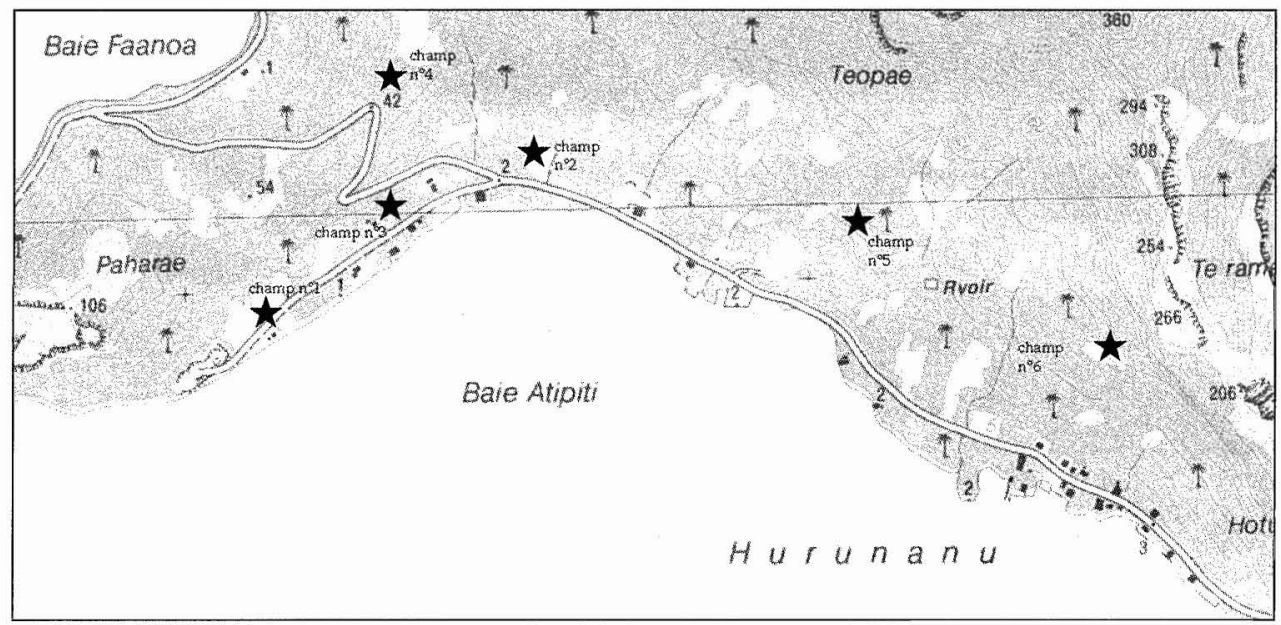

Fig. 2. The Ta'atoi region of Maupiti, showing the locations of studied gardens (after Ministère de l'Equipement 1986, 1:30,000). 
ence in rainfall between both types of locations, evaporation is greater and more rapid in these coastal fields. Purau (Hibiscus tiliaceus) and coconut (Cocos nucifera) leaves are used on the ground as mulch to help retard evaporation, especially in the coastal plain gardens.

\section{CULTIVATED SPECIES AND CULTURAL PRACTICES}

Seven main species are cultivated in Maupiti. The traditional crops are taro (Colocasia esculenta), yam (Dioscorea sp.), banana (especially fe' $i$ or Musa troglodytarum), and sweet potato ('umara, Ipomea batatas). The 'ape (Alocasia maccrorhiza) is abundant in Maupiti, but it is rarely eaten and not cultivated any longer. Tarua (Xanthosoma saggitifolium) and manioc (Manihot esculenta) were also taken into account, even though they were introduced during the post-contact period; they now play an important role in dryland horticulture and their presence cannot be neglected.

There are several varieties within each species. Some of them must be recent introductions, but this is difficult to verify because there are not many names of ancient varieties in the ethnohistoric literature (Henry 1993; Petard 1986). Furthermore, the scientific identification of some of these varieties remains uncertain. This was especially the case for yams; 11 different vernacular names were found in Maupiti. The only one found in the ethnohistoric sources is the pirita (Dioscorea nummularia).

In general, the species are distinguished according to color and morphological criteria: color of leaves, stems or tubers, shape of tuber or fruit, particular morphological details such as the presence of thorns on the stem (tararoti or "pink thorn" for a special kind of yam).

The following is a summary of our observations concerning techniques used in the different fields for each cultivated species. The preparation of the ground is roughly the same for all the cultivated species; the ground is cleaned with a knife or just with the hands, and then is turned over with an iron stick, which is used in the same manner as the ancient wooden planting stick. Another kind of wooden stick (about $20 \mathrm{~cm}$ in diameter) is used for making holes, especially for planting taro.

\section{The Yam (Ufi, Dioscorea sp.)}

In Maupiti, yams are cultivated on the coastal plain and in the mountains for two purposes: personal consumption or for a special competition called the tiurai (or July period). Eleven different kinds of yams were known in 1998: tararoti, tanetepu, matoha, matoha tanetepu, ti'ahiti (which means lateral), pirita (Dioscorea nummularia), rutu (also designates a "special kind of mountain plantain"), ta'ota'o (means "very dark"), "ufi "umara, "ufi 'oviri (means "wild yam" even if it is cultivated), and mata'o fa ' $i{ }^{4}$ For both type of yams (competition and consumption), a small shoot is planted on a little mound. Different techniques are used for competition and consumption yams.

The Competition Yam - This kind of yam is grown with the help of special elevated rectangular wooden structures. The structures, made of purau (Hibiscus tiliaceus), look like a kind of table with an empty center divided by five or six wooden 


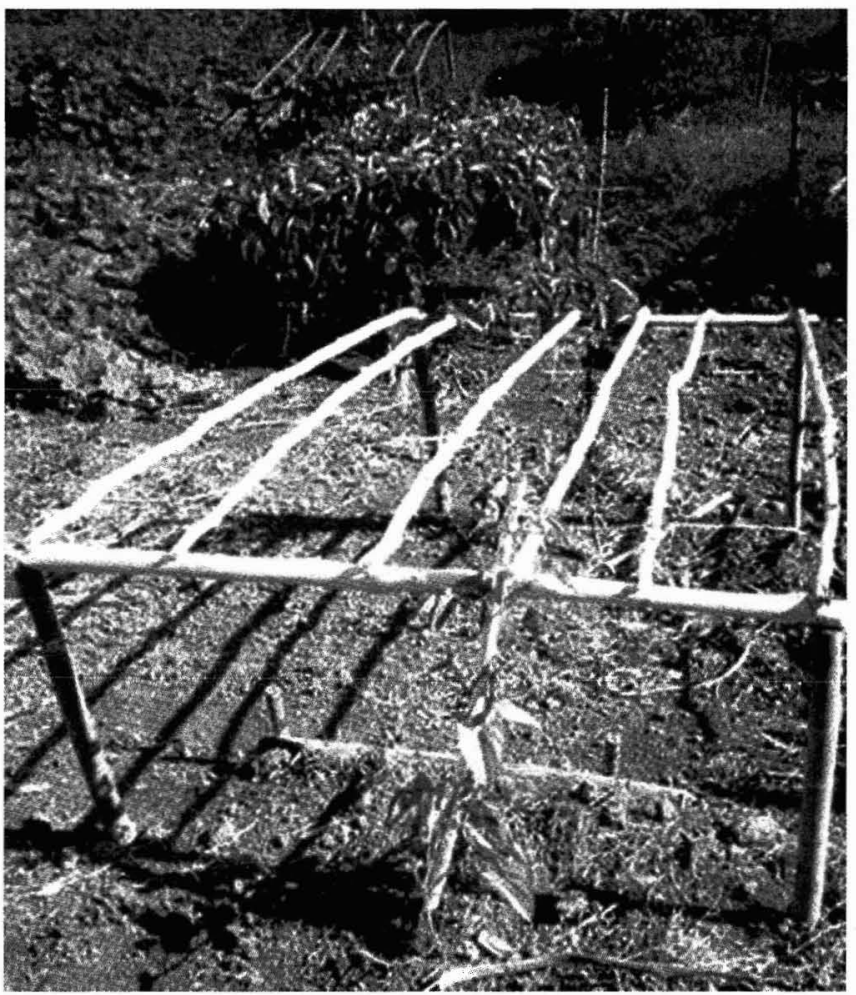

Fig. 3. Wooden structure used for growing competition yams.

sticks (Fig. 3). Each structure is from 2 to $2.5 \mathrm{~m}$ long, about $1.50 \mathrm{~m}$ wide, and 1 $\mathrm{m}$ high. Several structures can be strung together. Tubers are planted in 1- to 1.5m-diameter holes, depth can vary from 1 to $2 \mathrm{~m}$. The hole may be covered with dry coconut (Cocos nucifera) and purau (Hibiscus tiliaceus) leaves to protect against moisture loss, weeds, and damage caused by chickens. Some chemical fertilizer was used in the four gardens where competition yams were cultivated. When the garden is on a slope, "erosion beds" made of stones and purau pieces are placed just in front of the structure, under the central portion of the structure, or just around the planting hole (Fig. 4). The stones are placed in a semicircle in front of the structures in some cases (Fig. 5), and reinforced by a big piece of purau wood. The maturation period varies between 10 and 12 months.

On the whole, the planting/harvest periods are organized around the tiurai period (tiurai, 'July'). Yams are generally planted between July and September with a short fallow period ranging from two weeks to one month. There is an exception among the different examples: in one of the gardens, the fallow period is six months long in general; yams are planted either in January or July, harvested one year later, and the ground left fallow for six months. During the fallow period, holes are covered by purau and coconut leaves in order to preserve moisture. Hand-weeding is done every day.

Only two farmers use the lunar calendar to plant their yams (both competition and consumption); they plant them either just after the new moon ('ava'e 'api) or 


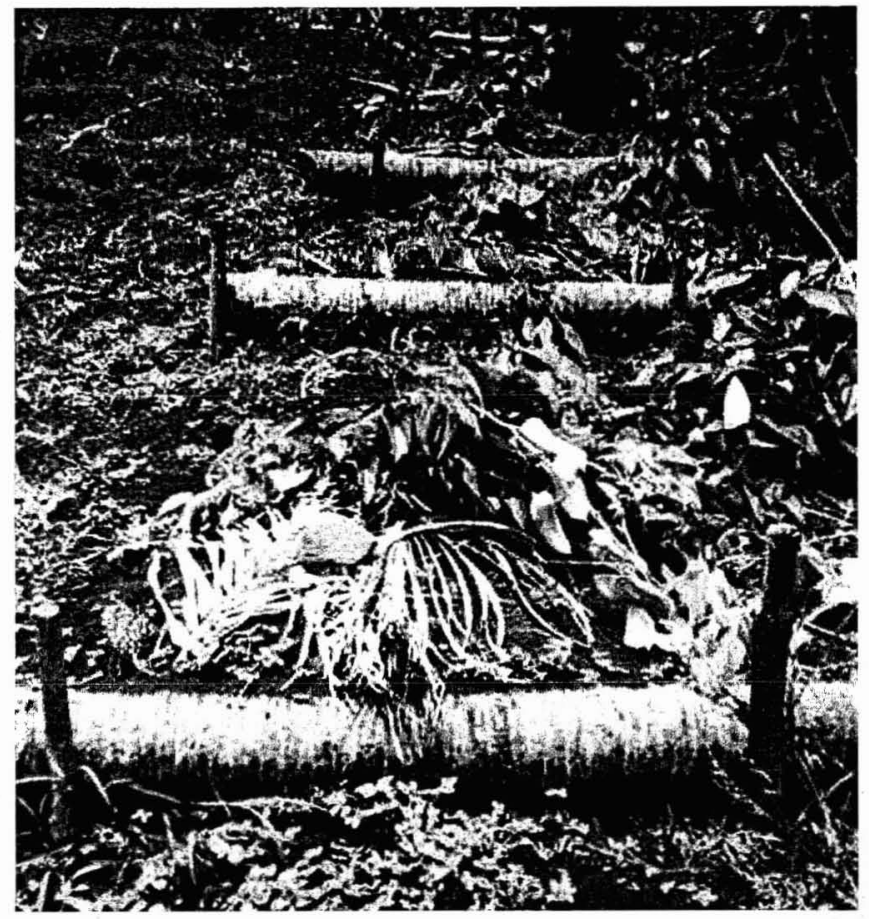

Fig. 4. Erosion control structures made of purau trunks.

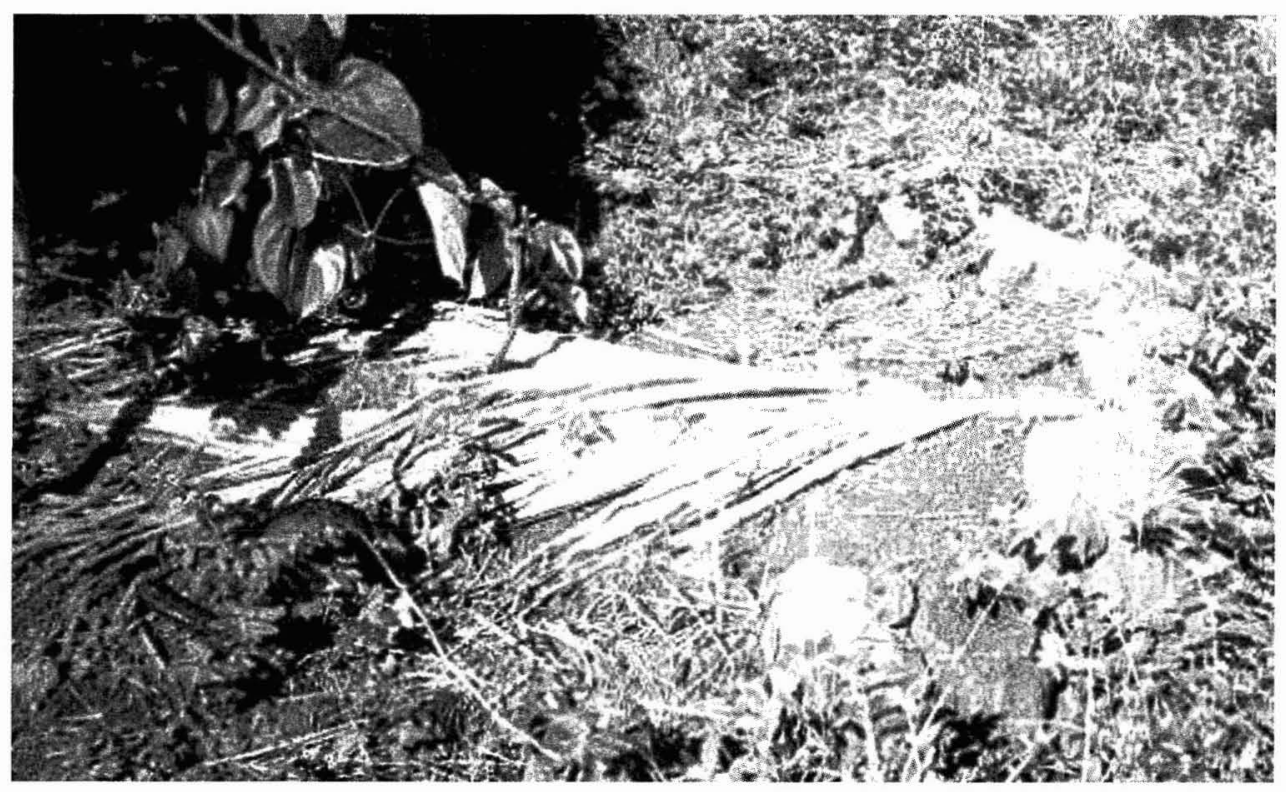

Fig. 5. Erosion control structure of basalt stones and coconut leaf mulch. 
the full moon ('ava'e 'atira) because they feel that yams planted at these periods grow better.

Just after the harvest period, a selection is made of yams intended for replanting, for sale, and those for consumption. ${ }^{5}$ Tubers are stored in a dry place at home, elevated, and protected from the light. When the fallow period is short, yams (shoots) intended for replanting can be stored on the ground near the place where they will be planted. In general, the farmers store their yams for four months at the most.

The Consumption Yam - These are generally planted either in small mounds or with the help of wooden poles (purau) that lay directly on the ground. Several tubers can be planted in the same hole (two to five, according to the different gardens), which average 80 to $100 \mathrm{~cm}$ deep and $80 \mathrm{~cm}$ wide. Those which are planted in small mounds are covered with earth and vegetal matter. This technique is employed in general for gardens located on a slope (around 20 to 30 percent). In addition to these two main techniques, some tubers are planted with the help of living purau poles (Fig. 6). These are young, thin stems of purau wood on which yam vines can better develop.

Yams can also grow in holes filled with earth without any pole to support the vines, but this is quite rare. Chemical fertilizer is used only by farmers who grow and eat competition yams.

The maturation period is also around one year long for consumption yams. The planting period takes place between July and October. The fallow length varies between two weeks and three months at the most. In one garden, there was no fallow period at all. During this period, the ground is maintained in the same way as competition yams (regular clearing, maintenance of moisture with compost, etc.). Both types of yams are stored in the same conditions.

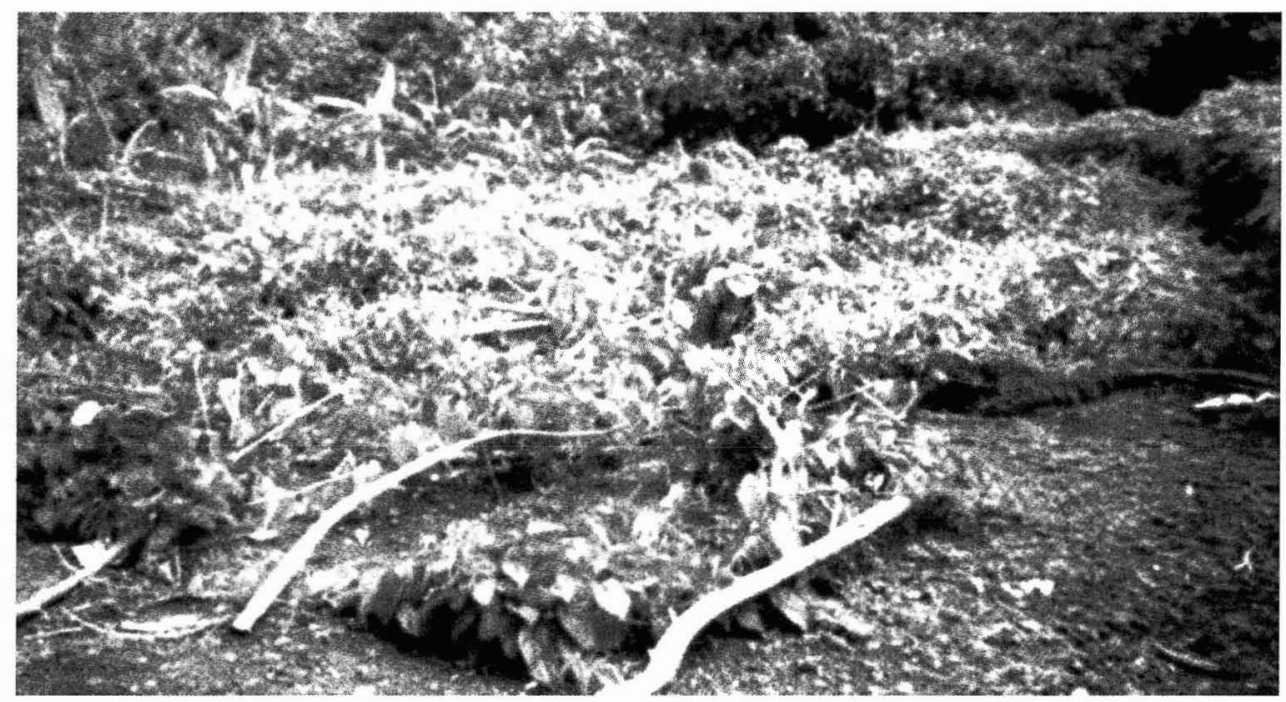

Fig. 6. Yam vines growing on purau poles. 


\section{The Taro (Colocasia esculenta)}

A whole shoot is vertically planted (entire leaf, stem, and "head" of the tuber), preferably during rainy conditions. The space between each planting hole is around 1 to $1.5 \mathrm{~m}$. The planting period is between July and October, and the maturation period is around 8 to 9 months. Taro seems to be planted almost yearround. Most taro farmers pay particular attention to the lunar calendar: taro shoots are planted during the days following the full moon ('ava'e 'atira) or the new moon ('ava'e 'api). The harvest period varies as taro is planted at different periods. With the exception of one farmer, this species is not presented for the tiurai competition. The fallow period is short, from a few days to one month at maximum. Taro is stored in the same conditions as yams, in a dry and elevated place, but for a shorter time.

\section{The Sweet Potato (Ipomea batatas, 'umara)}

The sweet potato is not a common cultigen in Maupiti. It is planted by cuttings and several stems are entwined between them, either in a semicircle or in a horizontal position. Then, the cuttings are planted in small mounds arranged in rows (Fig. 7), and the leaves (compost) laid on the ground. The space between each row of mounds is about $2 \mathrm{~m}$ and the mounds are $80 \mathrm{~cm}$ wide. The maturation period varies between three and six months according to the frequency of the rains. We have no precise information about the fallow period and the storage length. The fallow period is quite short. During that short period, burning can be used to extend the planting area but this practice is supposed to be rare. The process of sweet potato cultivation is intensive as are most of the species cultivated in Maupiti.

\section{The Banana (Musa sp.)}

The banana is cultivated in both the mountains and on the coastal plain. On flat fields, banana trunks can be arranged as field borders, especially when a cultivated

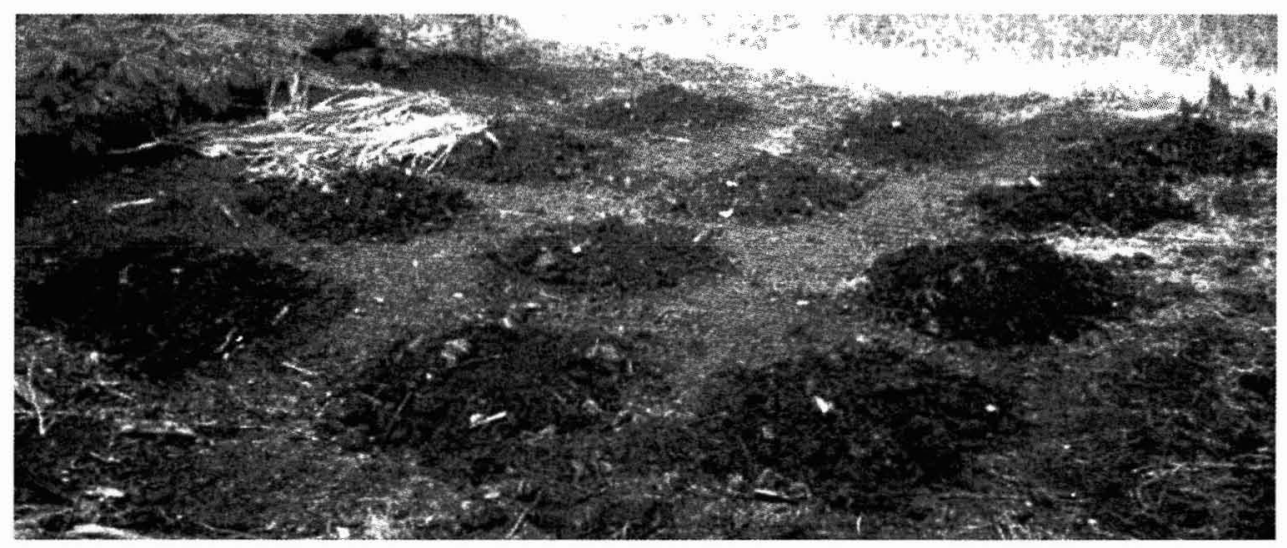

Fig. 7. Sweet potato planting mounds in rows. 
space is located on an indivisible field. ${ }^{6}$ The banana tree develops by vegetative reproduction. The ground is prepared in the same way as for the other species. One of the farmers uses a pointed purau-wood stick to dig, in contrast with most of his colleagues who use an iron tool for this purpose. A whole shoot is planted in a hole $50-100 \mathrm{~cm}$ in diameter and depth. When the shoot is in place, the hole is filled with earth and purau leaves. The banana tree can be surrounded with stones in order to stabilize it against the wind. Some of the fields where banana trees are cultivated have a steep gradient-from 25 to 40 percent. This kind of protection is necessary but, unfortunately, is not enough in the case of severe storms. For example, when cyclone Osea passed in 1997, most of the banana trees in mountain gardens were knocked down.

Bananas yield one year after planting. Only one of the farmers follows the lunar calendar for his bananas, which are planted the day following the full moon ('ava'e 'atira). The bunch is harvested while still green. It is suspended in a dry place for two to three days for further maturation before being eaten. After the harvest, a banana tree does not produce further, and its shoots are reused for future planting, which occurs a few days later without any particular fallow period.

\section{POTENTIAL YIELDS}

Potential yields have been calculated according to the number of plants by species/variety and by cultivated field for one year (Table 1). Average weights were determined for each pre-European species/variety in order to establish these calculations. It is important to emphasize that these numbers are estimates corresponding to a given period, in that they do not take into account potential annual variations. Indeed, cultivated species depend on rainfall even though they grow in a "dry" context. In fact, yields can be affected if the rainfall average is reduced and if there is no watering complement. Furthermore, the agronomic features related to this kind of calculation are quite complex and not applied here. Consequently, the results only give a rough idea of the potential yield, and are not intended to be considered definitive.

\section{THE PRIMARY PURPOSE OF CULTIVATION}

Different species are cultivated for three main purposes: household consumption, the tiurai (July) competition, and for sale. The first two are the most important for

Table i. Yield Estimates for Principal Crops

\begin{tabular}{lcc}
\hline CROP & $\begin{array}{c}\text { AVERAGE } \\
\text { YIELD/PLANT }\end{array}$ & $\begin{array}{r}\text { ESTIMATED YIELD } \\
\text { (TONS/HA/YEAR) }\end{array}$ \\
\hline Competition yams & $70 \mathrm{~g}$ & $10-47$ \\
Consumption yams & $545 \mathrm{~g}$ & $0.1-1.5$ \\
Taro & $500 \mathrm{~g}$ & $0.1-1.5$ \\
Sweet potato & $200 \mathrm{~g}$ & $0.02-0.2$ \\
Bananas & $20 \mathrm{~kg}$ & $1.6-13$ \\
\hline
\end{tabular}


the farmers. Sale of products seems not to be a priority and sales are restricted to Maupiti, except for one farmer who sells his products to Borabora Island. What is sold is always the surplus after retaining what is required for household consumption, and what is reserved for replanting. Most of the production is dedicated to personal consumption. This confirms that dryland horticulture in Maupiti is primarily small-scale and household-based.

Concerning the competition, the yam seems to be the competition species par excellence. ${ }^{7}$ The competition yam is cultivated in four of the six fields studied and grown with the use of chemical fertilizer. Its period of harvest coincides with the proximity of the competition, which takes place in July. This competition seems to have a prestigious character beyond its financial attraction. It is important to recall that in the Society Islands the yam did not have a great religious and social importance as it did in Melanesia during the pre-European period (Barrau 1965a, 1965b; Haudricourt and Hedin 1987). Especially in the Society Islands (and also Hawai'i), the most important period of the year for the presentation of earth products was the "first fruits" ceremony, called pararaa matahiti in Tahiti and makahiki in Hawai'i (Handy 1940; Henry 1993; Oliver 1974). Briefly, it took place between December and January during the main harvest period to offer thanks to the gods for a successful harvest, and to guarantee the fertility of the ground. It was also an opportunity to ask for good future harvests. ${ }^{8}$ We have no particular information about special competitions for agricultural products occurring during the pre-European period. The tiurai competition is an important part of Maupiti horticulture as it is in many other islands in French Polynesia. It corresponds to an event of recent origination.

\section{THE TIURAI COMPETITION}

The most interesting information to be found about this competition is by Oliver in his anthropological study Two Tahitian Villages (Oliver 1981). Comparing the social life in Mo'orea and Huahine in the 1950s, he explains that the competition had a double function, social and economic, which permitted farmers to win prizes while giving the farmer a certain prestige. According to his information, this competition was instituted by the French colonial administration around 1950 in order to encourage the cultivation of traditional staple species. The yam and the taro were the privileged species. The period of the competition in Mo'orea and Huahine was different from Maupiti. It took place between the middle and end of May, following one of the three harvest periods mentioned by Oliver's informants.

The basic technical features employed in Maupiti are quite similar to those described by Handy (1940) for the Hawaiian archipelago, or by Kirch (1976, 1994) for Western Polynesia. Despite a kind of continuity in traditional practices, several aspects show "recent" 9 technical transformations; the farmers no longer plant according to special periods (the lunar calendar) related to the different species. Nevertheless, most of them take into account the full and the new moon. Some chemical fertilizer is used, especially for the yam competition and sometimes for tarua, taro, and sweet potato. Chemical fertilizer does not increase yields compared to the pre-European period, ${ }^{10}$ but reduces fallow length, which 
enables planting in an almost continuous way. However, yields tend to become less important at harvest.

In Maupiti, fallow length is reduced in the mountains and on the coastal plain. Burning, which was one of the major shifting cultivation features elsewhere, is seldom employed. Two of the farmers who cultivate in the mountains stopped burning their fields about ten years ago, which almost corresponds to the beginning of the climatic vicissitudes of El Niño in the Pacific (in their own words). They said that they stopped burning because it had become "dangerous."

Ground clearing is now done by hand. Chemical fertilizer or traditional mulch with vegetal matter is used.

An important element of these modifications is the recent practice of manual watering. According to the farmers, manual watering is done to compensate for the progressive dryness of the ground occurring over the past ten years and reinforced by the passage of the cyclone Osea in 1997. Some of the farmers complained about the lack of moisture in the soil despite the rainy season. However, two points concerning the dryness and the use of manual watering can be made; first of all, it seems that there are not enough cases to directly relate the dryness to El Niño. Blaming El Niño and the cyclone Osea should be considered an indigenous representation compared to the "objective reality" (according to an agronomist consulted during the project). Second, the use of manual watering is presented as a necessity against dryness but it should be seen as an opportunity of proximity. Indeed, the farmers use it in the coastal plains because it is available and restricted to a limited area. If the water network becomes extended in future years (which is not evident), it seems likely that the farmers with fields in the mountains will use it. On the whole, the cultural practices observed in Maupiti are the concerns of dryland horticulture. Nevertheless, we can suppose that the potential extension of the local water network in the years to come should generate a progressive mutation of the traditional features from dryland horticulture to one which is wet but nonirrigated nor drained.

\section{CONCLUSIONS}

Several perspectives derive from this fieldwork. From an anthropological point of view, this kind of investigation needs to be carried out on other islands, especially within the Society archipelago for which there is limited anthropological information concerning dryland horticulture. Douglas Oliver's work has already illustrated acculturation in the 1950 s concerning horticulture in Mo'orea and Huahine. New investigations need to be carried out without delay, especially on islands which have been relatively "protected" from mechanized agriculture. This kind of investigation should also be applied to wetland horticulture, ${ }^{11}$ notably in favorable areas such as Tahiti's peninsula (Tahiti Iti), on Mo'orea, and the Austral archipelago. Time is of the essence given the important changes occurring in local agriculture where "traditional" crops are becoming less important. Elderly informants who still have knowledge of traditional practices are becoming scarce, and they complain about the lack of interest on the part of the younger generation, both in agriculture and concerning their past in general.

My primary interest in this subject has been to achieve a better uilderstanding 
of ancient agriculture in French Polynesia. This fundamental aspect of ancient society has to be explored and developed, especially from an archaeological point of view. Concerning dryland horticulture, archaeological information is quite fragmentary: as Farrington explains (Farrington in Leach 1999:312), the archaeological identification of a dryland and intensive horticultural system is difficult. Archaeological remains of dryland systems are rare and not forthcoming about the nature of cultivated species or the degree of cultural intensification. The main archaeological features in dryland (and partly, wet) horticulture can be summarized as follows: terraces, stone alignments, "associated structures" such as storage pits, and permanent or temporary habitations. Indicators of anthropogenic actions underlying ancient horticultural practices are degraded soils supporting secondary growth and pyrophytic vegetation, charcoal, and deposition of sediments resulting from erosion.

Several questions are related to horticultural features. For example, the anthropogenic origin of some remains, such as charcoal, can be discussed in certain cases (e.g., Lepofsky 1995; Lepofsky et al. 1996). Natural factors should more often be taken into account for interpreting their origin. Another delicate question is the way a horticultural site's use can be read over time. Indeed, even if a radiocarbon date can give information about timing of a burning event, it does not answer questions about utilization length or a fallow period, or of a horticultural site in general. This is the reason why I do not consider as evident the easiness of "reading time" in some aspects of a horticultural site: "... fallow time is usually so visible and readily measurable ..." (Athens in Leach 1999:322).

For the moment, archaeology itself seems to be able to offer only partial answers to the way ancient horticulture might have been practiced. D. Yen's words seem the closest to reality when he says, writing about agriculture ${ }^{12}$ : “... recourse to prehistory and ethnohistory is the only way to obtain even a partially adequate picture of the systems that operated in pre-European times" (Yen 1974). The question now is what an ethnoarchaeological approach can offer to the understanding of ancient horticulture. My approach was developed by working on a small high island where I had the opportunity to study the features of contemporary dryland horticulture. It was partly initiated by the fact that no visible horticultural remains were found during an exhaustive archaeological survey of Maupiti. The study results are interesting on a small scale, and showed clearly the possibilities of former dryland cultivation in the mountains, even on steep slopes. The main features of dryland horticultural processes were studied, and showed some further opportunities for a broader study that could also be extended to wetland horticulture. (I began carrying out such work in Tahiti and Mo'orea in 2000.) Even if the features in those localities are different, the same approach may give interesting comparative results. The limits to this kind of approach are easily identified. Modern aspects of horticulture (chemical fertilizer, new varieties, less available space and denser population, progressive draining of wetland areas) are becoming more important even in remote areas such as the Australs.

Nevertheless, technical information can inform us about intangible data such as the potential possibility to cultivate a given space. Those data coupled with archaeological information, such as available horticultural space in a given area, should help to estimate potential yields and the level of population that might 
have been supported. This is one of the aspects that can be offered by an ethnoarchaeological approach, whose utility is best when carried out in conjunction with an archaeological investigation (e.g., Di Piazza 1993, 1995; Golson 1990). Some favorable areas should be resurveyed. In the Society Islands, some "wellknown" areas, such as the 'Opunohu Valley in Mo'orea, or the Fa'aroa Valley in Ra'iatea, offer good examples of the spatial repartition of horticultural remains and their relationship to other types of archaeological sites. The interior of Tahiti Nui (the main island) is a place that offers substantial space, but which is not yet well studied, and which should be the setting for new surveys. Some horticultural sites located in different environments should be chosen as test areas for excavation to get a global approach of dry and wetland cultivation locations. Studying the spatial relationship of archaeological sites in conjunction with different disciplines, such as geomorphology, botanical identification, and pedology, should be a way to get answers if the right questions are asked (Di Piazza 1997; Flenley 1994; Kirch 1977). These questions can be suggested by an ethnographic approach or conversely by archaeology, but the most reasonable approach should be an interaction between the two disciplines. Low island environments also have to be taken into account with their particular environmental and technical features. What we can hope for after the encouraging preliminary experience of Maupiti is the fact that the work of pioneers (including Barrau, Yen, Kirch, Spriggs, Bonnemaison, Golson, and many others) will be followed by studying ancient horticulture throughout the Pacific. Many of the ancient ways have been lost from French Polynesia, but a few people are still trying to remember them. Many people wish to know more about their ancestors.

\section{NOTES}

1. Following Jacques Barrau, I prefer the definition of "horticulture" instead of agriculture for Pacific island systems. Horticulture underscores the idea of a particular treatment for each cultivated tuber or fruit.

2. Philippe Couraud, Ingénieur-agronome, Service du Développement Rural, Pirae, Tahiti, French Polynesia.

3. Maurua in Maupiti kuterakkt means "the two things," in reference to the two cliffs which are at either end of the island: Hotuparaoa and Hotua'e. In the local oral tradition, they recall the tie between two brothers and their sister, Teurufa'atiu (Heipua Teariki Bordes, Service de la Culture et du Patrimoine, Punaauia, Tahiti, pers. comm.).

4. The farmers were not sure about the spelling of mata ofa $i$. I have found two different interpretations. The second one seems to fit better; (1) mata means 'eye/face/edge of tool' and ofa ' $i$ means 'stone'; (2) the second possibility could be mata'o fa' $i$ : mata'o meaning a 'sharp-pointed stick used to dig the earth', fa' $i$ meaning 'a hole within which one can throw refuse to make mulch’ (Dictionnaire Tahitien-Français, Académie Tahitienne, Fare Vana'a, 1999, Papeete, Tahiti).

5. Some farmers eat these chemically fertilized yams even though they know that it is bad for one's health, and they recognize that the taste is quite poor.

6. The traditional land system is still in use but quite modified and regulated by the French Code Civil. This complex situation generates many familial problems, including agricultural use of the land.

7. The yam seems to be the favorite competition species today throughout the Society Islands. During the tiurai period, many local newspapers publish the results of the competitions, which are based on the biggest yam.

8. Another ritual took place around March-April in Tahiti to end the season of abundance. After the gods and the chief received their portion of offerings, the remainder was redistributed. During this period, war was forbidden. Handy (1927:31) interprets the ritual distribution of the god's portion as signalling the symbolic end of warfare and allowing the peaceful redistribution of the food offerings. 
9. "Recent" in this context means an impossible to date period of time since the introduction of European culture and tools.

10. Philippe Couraud, pers. comm.

11. This is the case in Tahiti and Mo'orea.

12. Which can also be valid for other aspects of ancient life.

\section{REFERENCES CITED}

BARRAU, J.

1965a L'humide et le sec: An essay on ethnobiological adaptation to contrastive environments in the Indo-Pacific area. Journal of the Polynesian Society 74:329-346.

1965b Histoire et préhistoire horticoles de l'Océanie tropicale. Journal de la Société des Océanistes $21: 55-75$.

Best, E.

1925 Maori Agriculture: The Cultivated Food Plants of the Natives of New Zealand, with Some Account of Native Methods of Agriculture, its Ritual and Origin Myths. Dominion Museum Bulletin 9, Wellington.

BOSERUP, E.

1970 Evolution Agraire et Pression Démographique. Nouvelle Bibliothèque Scientifique. Paris: Flammarion.

Buck, P. H. (Te Rangi Hiroa)

1938 Ethnology of Mangareva. B. P. Bishop Museum Bulletin 157. Honolulu.

Cauchors, M. H.

1999 Unpublished Master's thesis, L’horticulture siche en Polynésie á l'éoch pré-européene: une approche ethnoarchéologique, Mémoire de Maitrise, Université de Paris-I, PantheonSorbonne.

CoOK, J

1998 Relations de Voyage Autour du Monde. Paris: La Découverte.

Di Piazza, A.

1993 Côté Jardin: Horticulture Vivrière des îles Wallis et Futuna. These du 3e c.: Universite Paris 1.

1995 Les paysagistes Océaniens: De la socialisation à la natur, in Milieux, Sociétés et Archéologues: 25-33, ed. A. Marliac. Paris: ORSTOM.

1997 Eléments pour l'identification de plantes alimentaires océaniennes carbonisées. Journal d'Agriculture Traditionnelle et de Botanique Appliquée, pp. 75-93. Paris: Muséum d'histoire naturelle.

FERdon, E. N.

1981 Early Tahiti as the Explorers Saw It: 1767-1797. Tucson: University of Arizona Press.

FLenley, J. R.

1994 Pollen in Polynesia: The use of palynology to detect human activity in the Pacific islands, in Tropical Archeobotany, Applications and New Developments: 202-214, ed. J. Hather. London: Routledge.

Golson, J.

1990 Kuk and the development of agriculture in New Guinea: Retrospection and introspection, in Pacific Production Systems: Approaches to Economic Prehistory: 139-145, ed. D. Yen and J. Mummery. Canberra: Australian National University.

HANDY, E.S.C.

1923 The Native Culture of the Marquesas. B. P. Bishop Museum Bulletin 9. Honolulu.

1927 Polynesian Religion. B. P. Bishop Museum Bulletin 34. Honolulu.

1940 The Hawaiian Planter, vol. 1. B. P. Bishop Museum Bulletin 161. Honolulu.

Haudricourt, A. G., And L. Hedin

1987 L’homme et les Plantes Cultivées. Paris: Métailié.

Henry, T.

1993 Tahiti aux Temps Anciens, Publications de la Sociét des Océanistes, No. 1. Paris: Musée de l'Homme. 
KIRCH, P. V.

1976 Ethnoarchaeological investigations in Futuna and Uvea: A preliminary report. Journal of Polynesian Society 85:27-69.

1977 Valley agricultural systems in prehistoric Hawaii: An archaeological consideration. Asian Perspectives 20:246-280.

1994 The Wet and the Dry: Irrigation and Agricultural Intensification in Polynesia. Chicago: University of Chicago Press.

LEACH, H. M.

1999 Intensification in the Pacific, a critique of the archaeological criteria and their application. Current Anthropology 40:311-335.

LEPOFSKY, D.

1994 Prehistoric Agricultural Intensification in the Society Islands. Unpublished Ph.D. diss., University of California, Berkeley.

1995 A radiocarbon chronology for prehistoric agriculture in the Society Islands, French Polynesia. Radiocarbon 37:917-930.

Lepfosky, D., P. V. Kirch, AND K. Lertzman

1996 Stratigraphic and paleobotanical evidence for prehistoric human-induced environmental disturbance on Mo'orea, French Polynesia. Pacific Science 50:253-273.

MÉtraux, A.

1941 L'île de Pâques, Paris: Editions Gallimard.

OLIVER, D. L.

1974 Ancient Tahitian Society, 3 vols. Honolulu: University of Hawai'i Press.

1981 Two Tahitian Villages, A Study in Comparison. Laie: The Institute for Polynesian Studies.

Petard, P.

1986 Plantes Utiles de Tahiti. Papeete: Haere Po no Tahiti Editions.

YEN, D. E.

1974 The Sweet Potato in Oceania: An Essay in Ethnobotany. B. P. Bishop Museum Bulletin 236. Honolulu.

\section{ABSTRACT}

Maupiti (Society Islands, French Polynesia) is a small high island where dry and nonmechanized horticulture is still practiced. These practices can be seen in small orchard-gardens on the coastal plain and on mountainsides. Dryland cultures can seldom be organized in larger fields in the mountain, where staple species such as taro and bananas can be mixed among fallow.

A quasi-exhaustive archaeological survey has been made in Maupiti and no evidence of prehistoric horticultural remains were found. This lack of archaeological remains and the presence of several dryland orchard-gardens were the beginning of a study whose main purpose was to try to understand how dryland horticulture should appear in the archaeological record. KEYwords: horticulture, Maupiti, Society Islands, French Polynesia, ethnoarchaeology, agriculture, dryland horticulture, burning. 